\title{
Cobalt-Platinum Heterometallic Clusters Containing N-Heterocyclic Carbene Ligands
}

\author{
Bo Yang Chor, ${ }^{1,2}$ Wei Xiang Koh, ${ }^{1}$ Rakesh Ganguly, ${ }^{1}$ Yongxin Li, ${ }^{1}$ Luwei Chen, ${ }^{2}$ Robert Raja, ${ }^{3}$ and \\ Weng Kee Leong ${ }^{1, *}$ \\ ${ }^{1}$ Division of Chemistry \& Biological Chemistry, Nanyang Technological University, 21 Nanyang \\ Link, Singapore 637371. \\ ${ }^{2}$ Institute of Chemical and Engineering Sciences, 1 Pesek Road, Singapore 627833 \\ ${ }^{3}$ School of Chemistry, University of Southampton, Southampton SO17 1BJ, U.K.
}

\begin{abstract}
The heteronuclear cobalt-platinum cluster $\left[\mathrm{Co}_{2} \mathrm{Pt}_{2}(\operatorname{IPr})_{2}\left(\mu_{2}-\mathrm{CO}\right)_{4}(\mathrm{CO})_{4}\right]$ can be obtained through an addition reaction in $\left[\mathrm{Co}_{2}(\mathrm{CO})_{8}\right]$, and with subsequent cluster fragmentation in $\left[\mathrm{Co}_{4}(\mathrm{CO})_{12}\right]$ and $\left[\mathrm{Co}_{3}\left(\mu_{3^{-}}\right.\right.$ $\left.\mathrm{CH})(\mathrm{CO})_{9}\right]$, upon reaction with the $[\mathrm{Pt}(\mathrm{IPr})]$ fragment. The last reaction also afforded another cobaltplatinum cluster $\left[\mathrm{Co}_{4} \mathrm{Pt}_{2}\left(\mu_{6}-\mathrm{C}\right)(\mathrm{IPr})_{2}\left(\mu_{2}-\mathrm{CO}\right)_{5}(\mathrm{CO})_{6}\right]$. These are the first examples of Co-Pt heteronuclear clusters containing NHC ligands.
\end{abstract}

Keywords: Cobalt; platinum; heteronuclear carbonyl clusters; NHC

Dedicated to Professor Richard D. Adams on his 70th birthday.

\section{Introduction}

The cobalt-platinum bimetallic system has been known to be effective catalysts for FischerTropsch synthesis [1]. It has also been used as oxidation catalysts, such as, for methanol electrooxidation in the Direct Methanol Fuel Cell (DMFC), toluene combustion, and preferential CO oxidation reactions [2]. The use of heterometallic carbonyl clusters as a single-source precursor for such bimetallic systems have proven to afford catalysts which show superior performance to those prepared with traditional salt-impregnation methods [3] but to-date, cluster-derived cobalt-platinum catalysts have only been tested for the hydrogenolysis and demethylation of methylcyclopentane [4]. This strategy is, however, contingent upon the availability of suitable cluster precursors thus making the synthesis of heterometallic clusters a desirable endeavour.

\footnotetext{
* Corresponding author. Tel: +65 6592 7577. E-mail: chmlwk@ntu.edu.sg
} 
Cobalt carbonyl clusters which make suitable precursors for the synthesis of heterometallic clusters with varying metal ratios include $\left[\mathrm{Co}_{2}(\mathrm{CO})_{8}\right](\mathbf{1}),\left[\mathrm{Co}_{3}\left(\mu_{3}-\mathrm{CH}\right)(\mathrm{CO})_{9}\right](2)$ and $\left[\mathrm{Co}_{4}(\mathrm{CO})_{12}\right](3)$ because they are readily accessible. The addition of unsaturated $\left[\mathrm{Pt}\left(\mathrm{PR}_{3}\right)\right]$ fragments, generated in situ via the loss of the ethylene ligand from $\left[\mathrm{Pt}\left(\mathrm{C}_{2} \mathrm{H}_{4}\right)_{2}\left(\mathrm{PR}_{3}\right)\right]$, to cobalt carbonyl clusters have been reported. For example, the reaction with 2 gave two addition products, $\left[\mathrm{Co}_{3} \mathrm{Pt}_{2}\left(\mu_{2}-\mathrm{H}\right)\left(\mu_{5}-\mathrm{C}\right)\left(\mathrm{PPr}_{3}^{\mathrm{i}}\right)_{2}(\mathrm{CO})_{9}\right]$ and $\left[\mathrm{Co}_{3} \mathrm{Pt}_{3}\left(\mu_{2}-\mathrm{H}\right)\left(\mu_{6}-\mathrm{C}\right)\left(\mathrm{PPr}_{3}^{\mathrm{i}}\right)_{3}(\mathrm{CO})_{9}\right]\left(\right.$ Scheme 1) [5]. In contrast to the chemistry of $\left[\mathrm{Pt}\left(\mathrm{PR}_{3}\right)\right]$ fragments, the addition of $[\mathrm{Pt}(\mathrm{NHC})]$ (where $\mathrm{NHC}=\mathrm{N}$-heterocyclic carbene) fragments onto cobalt carbonyl clusters is as yet unknown. We recently showed that the reactive $[\mathrm{M}(\mathrm{NHC})]$ (where $\mathrm{M}=\mathrm{Pd}$ or $\mathrm{Pt}$ ) fragments, generated in situ from [M(NHC)(allyl)Cl], could successfully add across Os-Os bonds [6]. Our work with the cobalt carbonyl clusters 1-3 is reported here.

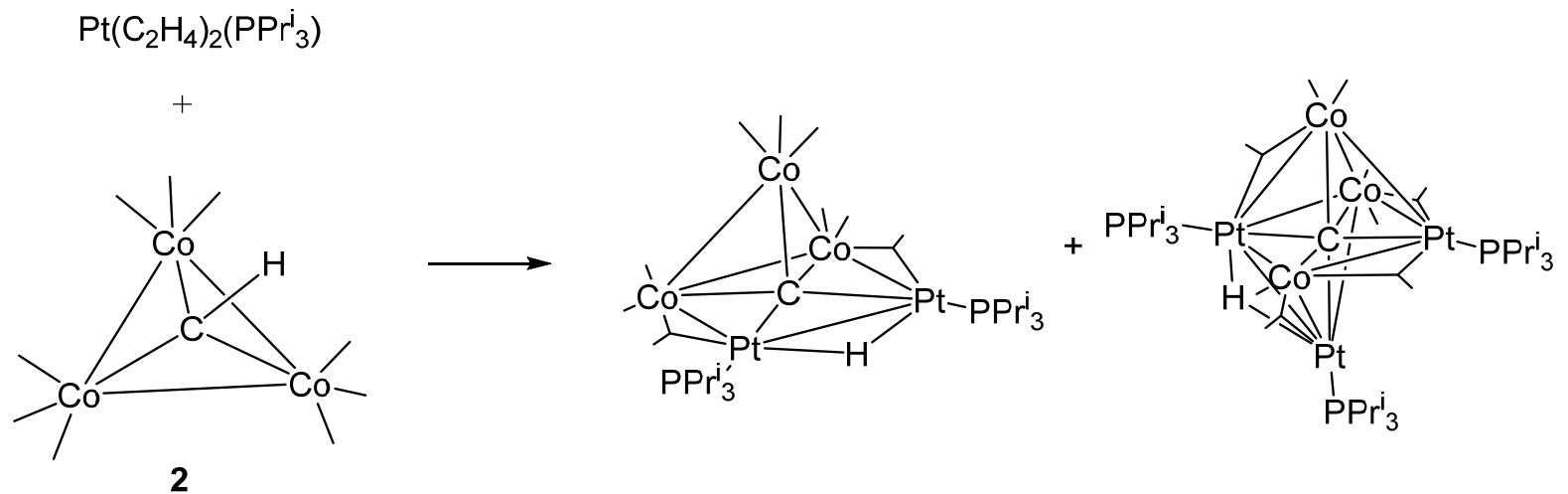

\section{Scheme 1}

\section{Results and discussion}

Room temperature reactions of the $[\operatorname{Pt}(\operatorname{IPr})]$ fragment (where $\operatorname{IPr}=[1,3-b i s(2,6-$ diisopropylphenyl)imidazol-2-ylidene]) (6), generated in situ from [Pt( $\mathrm{NHC})(2-m e t h y l p r o p e n y l) C l]$, with the cobalt carbonyl clusters 1-3 are summarised in Scheme 2. Both $\mathbf{1}$ and $\mathbf{3}$ reacted cleanly with two moles of 6 to afford the cluster $\left[\mathrm{Co}_{2} \mathrm{Pt}_{2}(\operatorname{IPr})_{2}\left(\mu_{2}-\mathrm{CO}\right)_{4}(\mathrm{CO})_{4}\right](4)$ as an air-stable, purple solid. The formation of $\mathbf{4}$ from $\mathbf{1}$ corresponds to the addition of two units of $\mathbf{6}$ while in the reaction of 3 , no $\mathrm{Co}_{4} \mathrm{Pt}_{\mathrm{x}}$ cluster was observed even with one molar equivalent of $\mathbf{6}$. The reaction involving 2 was more complicated, giving multiple products from which only 4 and another new cluster $\left[\mathrm{Co}_{4} \mathrm{Pt}_{2}\left(\mu_{6^{-}}\right.\right.$ $\left.\mathrm{C})(\operatorname{IPr})_{2}\left(\mu_{2}-\mathrm{CO}\right)_{5}(\mathrm{CO})_{6}\right](5)$ was isolated as an air-stable, green solid. Interestingly, the IPr analogues of 
the phosphine derivatives $\left[\mathrm{Co}_{3} \mathrm{Pt}_{2}\left(\mu_{2}-\mathrm{H}\right)\left(\mu_{5}-\mathrm{C}\right)\left(\mathrm{PPr}_{3}^{\mathrm{i}}\right)_{2}(\mathrm{CO})_{9}\right]$ and $\quad\left[\mathrm{Co}_{3} \mathrm{Pt}_{3} \quad\left(\mu_{2}-\mathrm{H}\right)\left(\mu_{6^{-}}\right.\right.$ $\left.\mathrm{C})\left(\operatorname{PPr}_{3}^{\mathrm{i}}\right)_{3}(\mathrm{CO})_{9}\right]$ given in Scheme 1 were not observed, even with various molar equivalents of [Pt(IPr)].

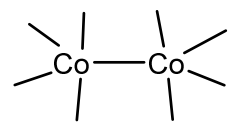

1
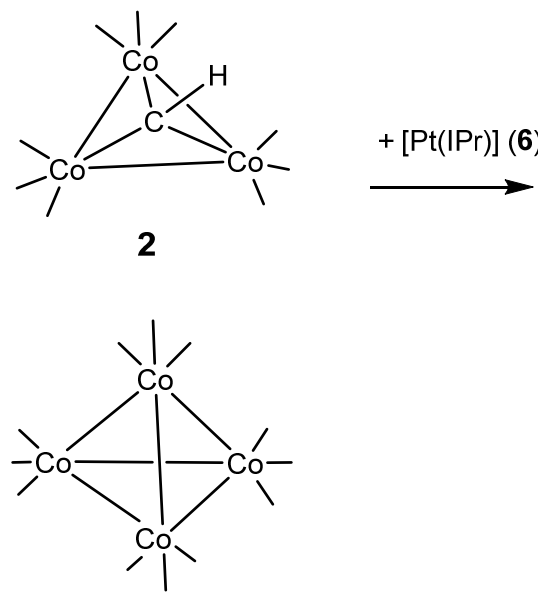

3

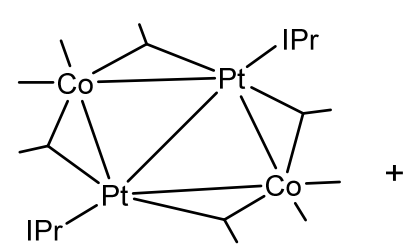

4

$1 \quad 82 \%$

$2 \quad 20 \%$

3

$56 \%$

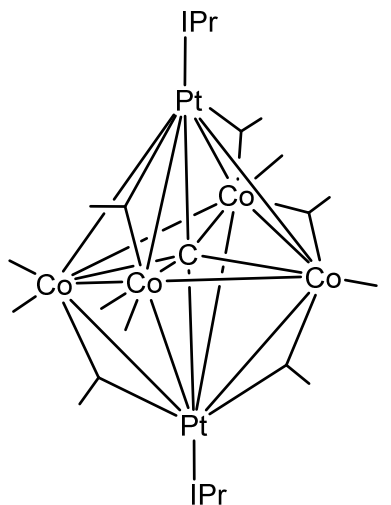

5

$29 \%$ + unidentified

\section{Scheme 2}

The molecular structures of $\mathbf{4}$ and $\mathbf{5}$ have been confirmed by single crystal X-ray crystallographic analyses. The ORTEP plot showing the molecular structure of $\mathbf{4}$, together with selected bond parameters, is given in Figure 1. The crystal of $\mathbf{4}$ exhibited disorder about a crystallographic mirror plane passing through the two $\mathrm{Pt}$ atoms. The molecule itself is located at a special position with $2 / \mathrm{m}$ symmetry, with the 2-fold rotation axis through the Pt atoms. The IR spectrum confirmed the presence of both terminal and bridging CO ligands, while the NMR spectrum showed one set of resonances for the IPr carbene ligand. 


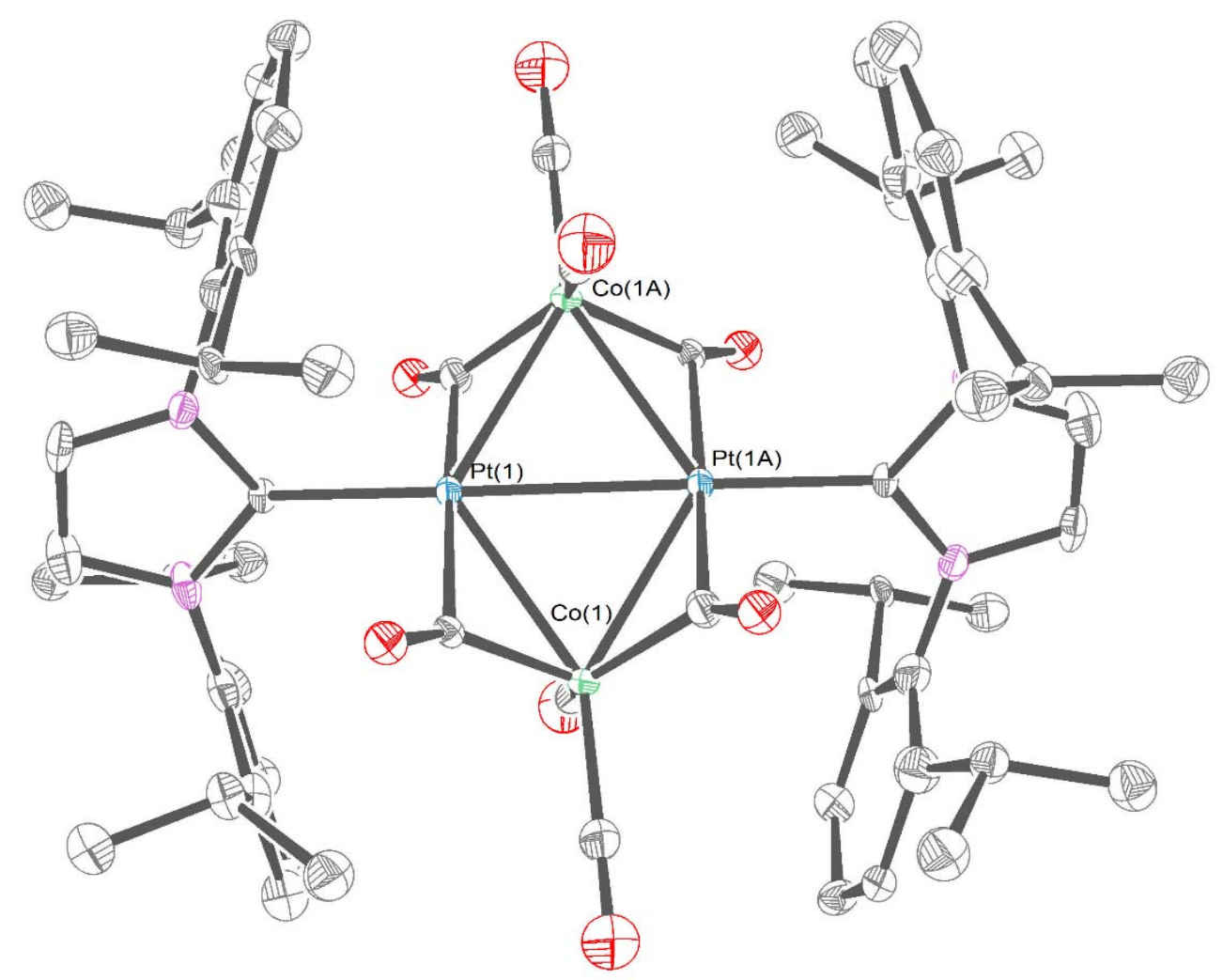

Figure 1. ORTEP diagram of cluster 4. Ellipsoids are drawn at 50\% probability level. Hydrogen atoms have been omitted for clarity. Selected bond lengths $(\AA)$ and angles $\left({ }^{\circ}\right)$ : $\operatorname{Pt}(1)-\operatorname{Pt}(1 \mathrm{~A})=2.7570(6), \operatorname{Pt}(1)-$ $\operatorname{Co}(1)=2.526(2) / 2.58226(2)^{*}, \operatorname{Pt}(1)-\operatorname{Co}(1 \mathrm{~A})=2.5918(19) / 2.5672(19)^{*}, \operatorname{Co}(1 \mathrm{~A})-\operatorname{Pt}(1)-\operatorname{Co}(1)=$ 114.83(5) / 115.26(5)*, $\operatorname{Co}(1)-\operatorname{Pt}(1)-\operatorname{Pt}(1 \mathrm{~A})=58.56(4) / 57.89(4)^{*}, \operatorname{Co}(1)-\operatorname{Pt}(1)-\operatorname{Pt}(1 \mathrm{~A})=56.27(5) /$ 57.37(4)*. *values for the other half of the disorder.

The valence electron count of 58 is in accord with the EAN rule for a 16-electron configuration for Pt. There is a Pt-Pt bonding interaction $(\operatorname{Pt}(1)-\mathrm{Pt}(1 \mathrm{~A})=2.7570(6) \AA)$, but no Co-Co bond $(\mathrm{Co}(1) \ldots \mathrm{Co}(1 \mathrm{~A}) \sim 4.349 \AA)$. This contrasts with its phosphine analogue $\left[\mathrm{Co}_{2} \mathrm{Pt}_{2}\left(\mathrm{PPh}_{3}\right)_{2}\left(\mu_{2}-\mathrm{CO}\right)_{3}(\mathrm{CO})_{5}\right]$ (4') which has a butterfly $\mathrm{Co}_{2} \mathrm{Pt}_{2}$ core, an intact Co-Co bond (2.498(3) $\AA$ ) and a Pt...Pt distance of 2.987(4) $\AA$ [7] (Figure 2). In comparison, the $\mathrm{Co}_{2} \mathrm{Pt}_{2}$ core in 4 is constrained by the crystallographic $2 / \mathrm{m}$ symmetry to be planar. This difference in skeletal arrangement is not uncommon in heteronuclear clusters, however. For example, while $\left[\mathrm{Mo}_{2} \mathrm{Pt}_{2}\left(\eta_{5}-\mathrm{C}_{5} \mathrm{H}_{5}\right)_{2}\left(\mathrm{PEt}_{3}\right)_{2}\left(\mu_{2}-\mathrm{CO}\right)_{6}\right]$ has a planar $\mathrm{Mo}_{2} \mathrm{Pt}_{2}$ core, the $\mathrm{PPh}_{3}$ analogue $\left[\mathrm{Mo}_{2} \mathrm{Pt}_{2}\left(\eta_{5}-\mathrm{C}_{5} \mathrm{H}_{5}\right)_{2}\left(\mathrm{PPh}_{3}\right)_{2}\left(\mu_{2}-\mathrm{CO}\right)_{4}(\mathrm{CO})_{2}\right]$ has a butterfly core [8]. Interconversion in 
solution between skeletal isomers is also possible, for example, the bulkier phosphine analogues $\left[\mathrm{Mo}_{2} \mathrm{Pt}_{2}\left(\eta_{5}-\mathrm{C}_{5} \mathrm{H}_{4} \mathrm{Me}\right)_{2}\left(\mathrm{PR}_{3}\right)_{2}(\mathrm{CO})_{6}\right]\left(\mathrm{R}=\mathrm{Cy}\right.$ or $\left.\mathrm{Pr}^{\mathrm{i}}\right)$ can exist in solution with both a planar and a tetrahedral core [9], although there is no evidence of this for cluster 4.

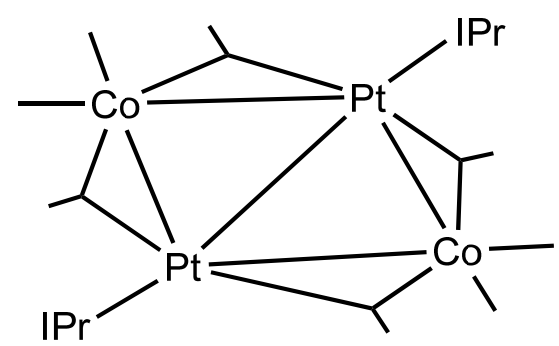

4

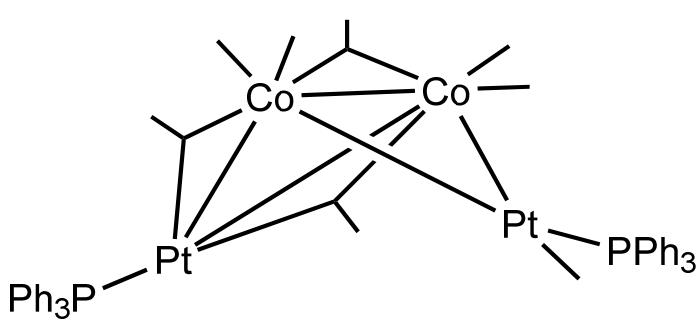

$4^{\prime}$

Figure 2. Molecular structures of $\mathbf{4}$ and $\mathbf{4}$ '.

The ORTEP plot showing the molecular structure of $\mathbf{5}$, together with selected bond parameters, is given in Figure 3. IR analysis confirmed the presence of both terminal and bridging CO ligands, while the NMR spectrum showed one set of resonances for the IPr carbene, consistent with the symmetry of the cluster. The $\mathrm{Co}_{4} \mathrm{Pt}_{2}\left(\mu_{6}-\mathrm{C}\right)$ core is a distorted octahedron, in accord with PSEPT for a cluster valence electron count of 86 , and the puckered basal plane is made up of the four cobalt atoms. This molecular geometry closely resembles that of the only known $\left[\mathrm{Pd}\left(\mathrm{PPh}_{3}\right)\right]$ analogue, $\left[\mathrm{Co}_{4} \mathrm{Pd}_{2}\left(\mu_{6}-\mathrm{C}\right)\left(\mathrm{PPh}_{3}\right)_{2}\left(\mu_{2^{-}}\right.\right.$ $\left.\mathrm{CO})_{5}(\mathrm{CO})_{6}\right]\left(5^{\prime}\right)[10]$ (Figure 4).

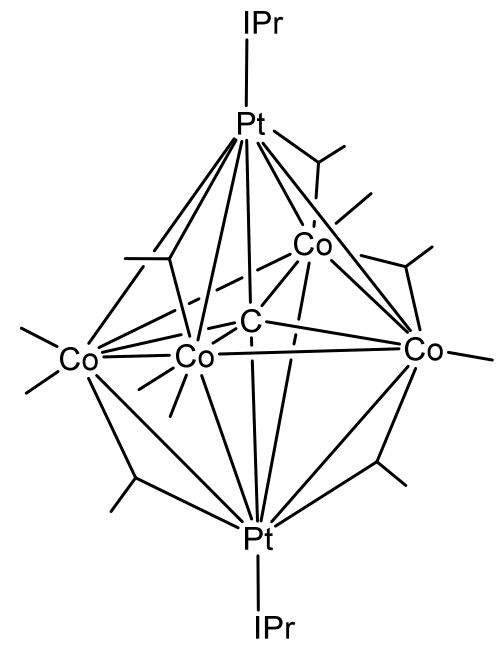

5

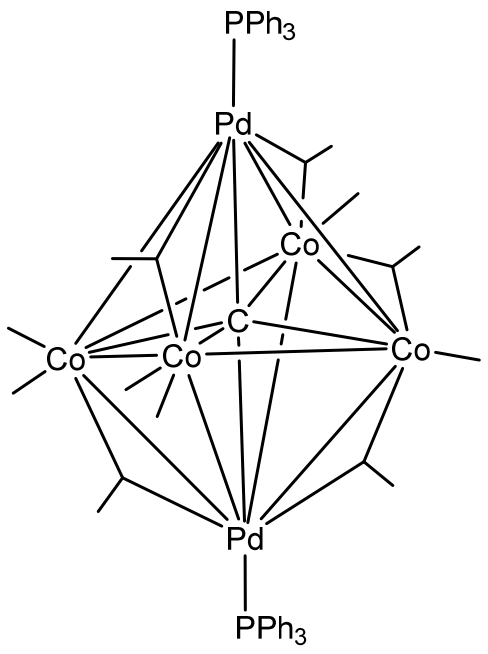

$\mathbf{5}^{\prime}$

Figure 4. Molecular structure of cluster 5 and 5'. 


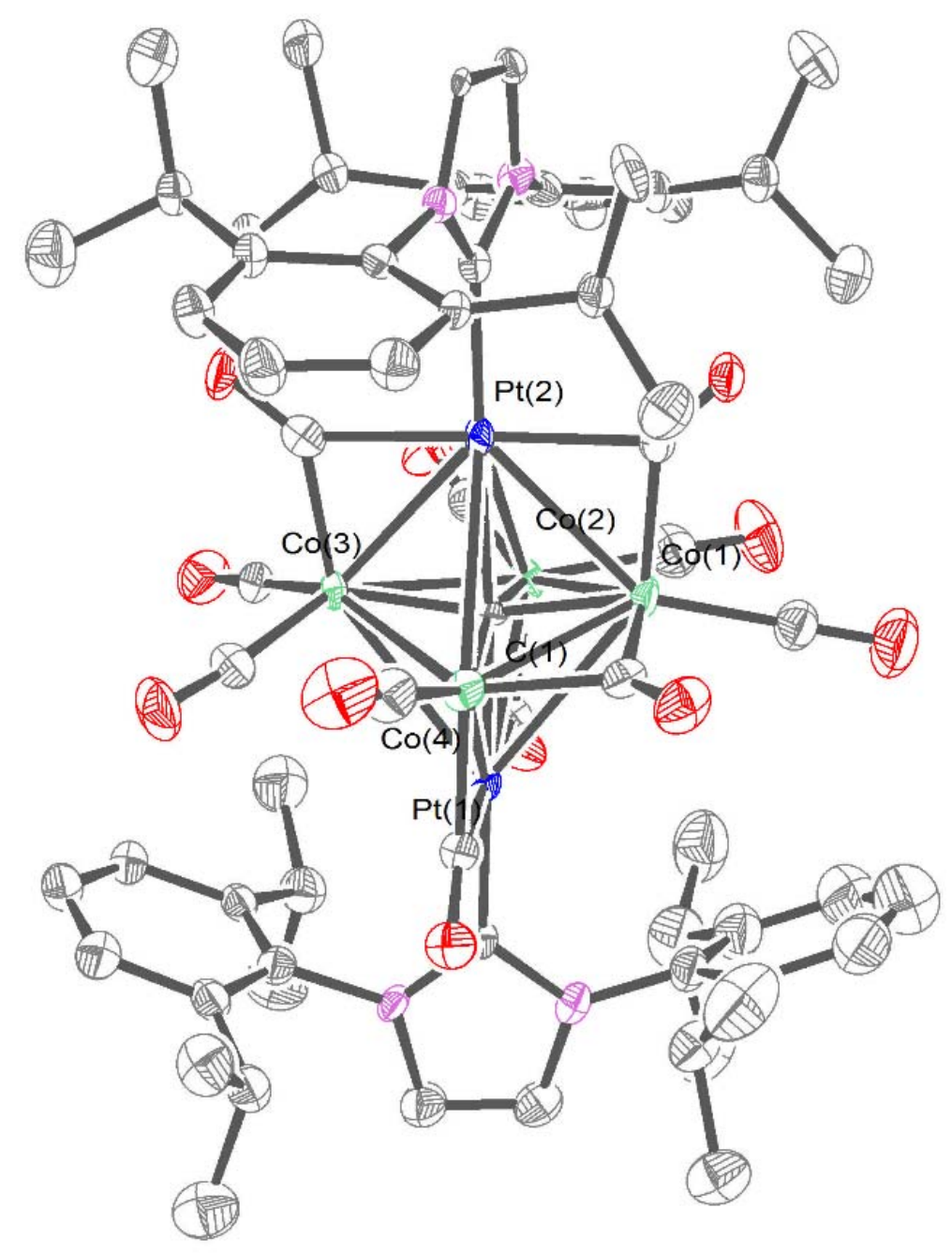

Figure 3. ORTEP diagram of cluster 5. Ellipsoids are drawn at $50 \%$ probability level. Hydrogen atoms have been omitted for clarity. Selected bond lengths $(\AA)$ : $\operatorname{Co}(1)-C(1)=1.880(13), \operatorname{Co}(2)-C(1)=$ 1.846(12), $\mathrm{Co}(3)-\mathrm{C}(1)=1.846(13), \mathrm{Co}(4)-\mathrm{C}(1)=1.869(12), \operatorname{Pt}(1)-\mathrm{C}(1)=2.123(12), \operatorname{Pt}(2)-\mathrm{C}(1)=$ 2.142(12), $\operatorname{Co}(1)-\operatorname{Co}(2)=2.705(3), \operatorname{Co}(1)-\operatorname{Co}(4)=2.518(3), \operatorname{Co}(2)-\operatorname{Co}(3)=2.698(2), \operatorname{Co}(3)-\operatorname{Co}(4)=$ 2.692(3), $\operatorname{Co}(1)-\operatorname{Pt}(2)=2.6359(19), \operatorname{Co}(2)-\operatorname{Pt}(2)=2.9791(18), \operatorname{Co}(3)-\operatorname{Pt}(2)=2.6322(19), \operatorname{Co}(4)-\operatorname{Pt}(2)$ $=3.0428(19), \operatorname{Co}(2)-\operatorname{Pt}(1)=2.6389(19), \operatorname{Co}(3)-\operatorname{Pt}(1)=2.8972(18), \operatorname{Co}(4)-\operatorname{Pt}(1)=2.6401(19), \operatorname{Co}(1)-$ $\operatorname{Pt}(1)=3.1303$. 
The Co- $\mathrm{C}_{\text {carbide }}$ and Co-Co bond lengths (1.846(12) - 1.869(12) and 2.518(3) - 2.705(3) $\AA$, respectively) in 5 are comparable to those in the homometallic, octahedral cluster $\left[\mathrm{Co}_{6}\left(\mu_{6}-\mathrm{C}\right)(\mathrm{CO})_{13}\right]^{2-}$ (1.852(3) - 1.880 and 2.4618(8) - 2.926(1) $\AA$, respectively) [11]. The Pt- $\mathrm{C}_{\text {carbide }}$ and the Co-Pt bond lengths (2.123(12) - 2.142(12) and 2.6322(19) $\AA$ - 3.1303(2) $\AA$, respectively) in 5 are also comparable to those found in $\left[\mathrm{Co}_{3} \mathrm{Pt}_{3}(\mu-\mathrm{H})\left(\mu_{6}-\mathrm{C}\right)\left(\mathrm{PPr}_{3}\right)_{3}(\mathrm{CO})_{9}\right](2.04(1)-2.16(1)$ and 2.598(3) - 3.060(3) $\AA$, respectively) [5]. One of the Co-Pt bonds $(\operatorname{Pt}(1)-\operatorname{Co}(1)=3.1303(2) \AA)$ is unusually long, which we believe may be due to the effects of crystal packing forces. An attempt was made to corroborate this via a natural bond orbital (NBO) analysis on 5 with density functional theory (DFT) at the def2SVP/6$31 \mathrm{G}^{*}$ level of theory. The Wiberg bond indices and metal-metal bond lengths for the optimised geometry are given in Figure 5.

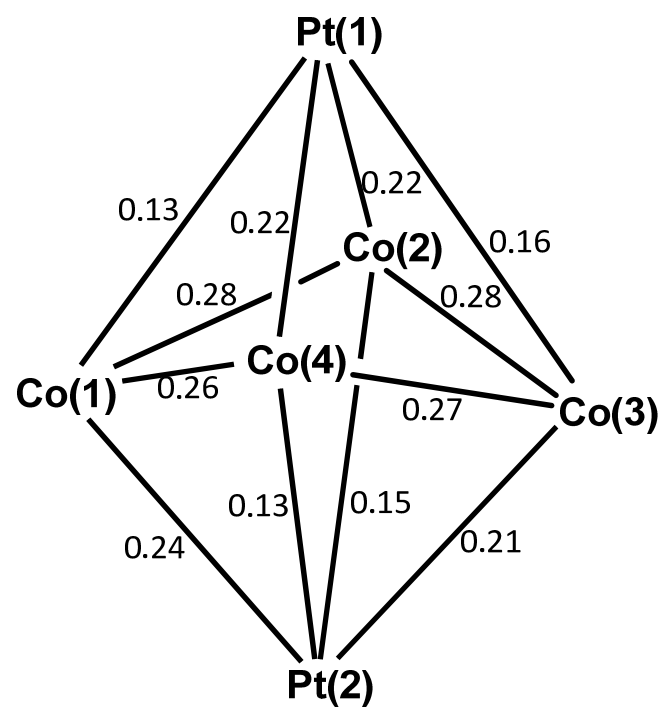

Wiberg bond index

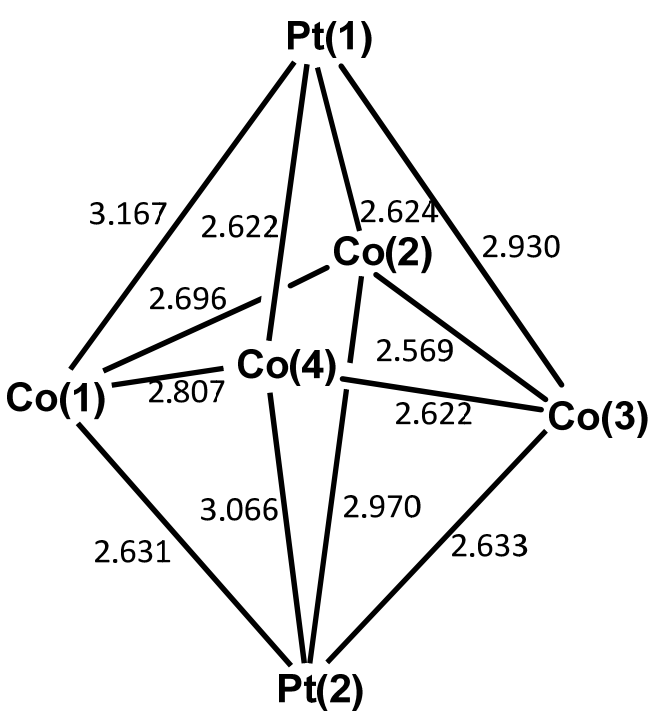

Optimised bond lengths $(\AA)$

Figure 5. Wiberg bond indices (left) and calculated metal-metal bond lengths in Å (right) for cluster 5.

The bond indices for the Co-Pt bonds can be divided into two sets, with values in the ranges 0.13-0.16 (Pt(1)-Co(1), $\operatorname{Pt}(1)-\operatorname{Co}(3), \operatorname{Pt}(2)-\operatorname{Co}(4)$ and $\operatorname{Pt}(2)-\operatorname{Co}(2))$, and 0.21-0.24 (Pt(1)-Co(4), $\operatorname{Pt}(1)-$ $\operatorname{Co}(2), \operatorname{Pt}(2)-\operatorname{Co}(1)$ and $\operatorname{Pt}(2)-\operatorname{Co}(2))$. They correlate well with both the calculated and experimental bond lengths; those with shorter bond lengths correspond to higher bond indices, in accord with the trend reported for metal-metal bonds [12]. Although there are no reports of bond indices for Co-Pt bonds, it has been reported that homonuclear metal-metal bonds such as the single Ru-Ru bond has 
bond index $\sim 0.2$ [13], and that for a single Fe-Fe bond has bond index $\sim 0.1$ [14]. The bond indices calculated here thus suggest that the $\mathrm{Pt}(1)-\mathrm{Co}(1)$ vector corresponds to a single metal-metal bond.

The formation of 4 and 5 requires a change in the nuclearity of the reactants 1-3. This may be attributed to the ease with which cobalt carbonyl clusters undergo cluster fragmentation/rearrangement and is not unprecedented. For example, reaction of the cluster $\left.\left[\mathrm{Co}_{6}\left(\mu_{6}-\mathrm{C}\right) \mathrm{CO}\right)_{15}\right]^{2-}$ with a lower molar equivalent of $\left[\mathrm{Au}\left(\mathrm{PPh}_{3}\right) \mathrm{Cl}\right]$ afforded a $\mathrm{Co}_{6} \mathrm{Au}_{\mathrm{x}}$ cluster, while use of a larger molar equivalent resulted in a reduction in nuclearity to afford $\mathrm{Co}_{4} \mathrm{Au}_{\mathrm{x}}$ and $\mathrm{Co}_{5} \mathrm{Au}_{\mathrm{x}}$ clusters [15]. In analogy to $\left[\mathrm{Co}_{4} \mathrm{Au}_{2}\left(\mu_{6}-\mathrm{C}\right)\right.$ $\left.\left(\mathrm{PPh}_{3}\right)_{2}(\mathrm{CO})_{10}\right]$, which has been regarded as a stabilized form of the unobserved anionic cluster $\left[\mathrm{Co}_{4}\left(\mu_{4^{-}}\right.\right.$ $\left.\mathrm{C})(\mathrm{CO})_{10}\right]^{2-}$ by two $\left[\mathrm{Au}\left(\mathrm{PPh}_{3}\right)\right]^{+}$fragments [15], the formation of 5 from 2 may thus be viewed as the stabilisation of the unobserved, neutral cluster $\left[\mathrm{Co}_{4}\left(\mu_{4}-\mathrm{C}\right)(\mathrm{CO})_{11}\right]$ by two $[\mathrm{Pt}(\mathrm{IPr})]$ fragments.

\section{Concluding remarks}

In this work, we reported that a $[\mathrm{Pt}(\mathrm{NHC})]$ fragment could react with a variety of cobalt carbonyl clusters (1-3) to give new heteronuclear cobalt-platinum clusters. The results show that the $[\mathrm{Pt}(\mathrm{NHC})]$ fragment added across Co-Co bonds but as is characteristic of cobalt carbonyl clusters, the reactions were accompanied by cluster fragmentation/rearrangement, and appeared to favour the formation of clusters $\mathbf{4}$ and $\mathbf{5}$ which presumably corresponded to "thermodynamic sinks" for these reactions.

\section{Experimental}

\subsection{General procedure}

All reactions were performed under an argon atmosphere using standard Schlenk techniques or in a glove box. Solvents used in reactions were of AR grade, and were dried over the appropriate drying agent, distilled under nitrogen and stored in flasks fitted with Teflon valves prior to use. Preparative TLC separations were carried out on Merck silica gel $60 \AA$ F $25420 \times 20 \mathrm{~cm}^{2}$ plates. ${ }^{1} \mathrm{H}$ NMR spectra were collected on a Bruker BBFO 400 or AV 300 NMR spectrometer, with chemical shifts referenced to the solvent residual peaks. High resolution mass spectra were recorded in electrospray ionization 
(ESI) mode on a Waters UPLC-Q-TOF mass spectrometer. Elemental analyses were performed by the microanalytical laboratory in NTU. $\left[\mathrm{Co}_{2}(\mathrm{CO})_{8}\right](\mathbf{1})$ and $\left[\mathrm{Co}_{4}(\mathrm{CO})_{12}\right](\mathbf{1})$ were purchased from Alfa Aesar, and the complexes $\left[\mathrm{Co}_{3}\left(\mu_{3}-\mathrm{CH}\right)(\mathrm{CO})_{9}\right](2)[16]$ and $\left[\operatorname{Pt} \operatorname{IPr}\left(\mathrm{C}_{4} \mathrm{H}_{7}\right) \mathrm{Cl}\right](6)$ [17] were prepared according to published methods. All other reagents were used as received from commercial suppliers.

\subsection{Reaction of 1 with $[\operatorname{Pt}(\mathrm{IPr})]$}

A sample of $6(30.0 \mathrm{mg}, 0.0445 \mathrm{mmol})$ and $\mathrm{KO}^{\mathrm{t}} \mathrm{Bu}(5.0 \mathrm{mg}, 0.045 \mathrm{mmol})$ in IPA $(5 \mathrm{~mL})$ were heated at $80^{\circ} \mathrm{C}$ for $1 \mathrm{~h}$ during which the initial colourless solution turned yellow. After removal of the solvent under vacuum, the yellow oil was re-dissolved in toluene $(10 \mathrm{~mL})$ to which 1 ( $7.6 \mathrm{mg}, 0.022$ mmol) was added. The solution turned red-purple and was left to stir at RT for $3 \mathrm{~h}$. After removal of the solvent, the residue was re-dissolved in the minimum volume of toluene and filtered through a thin pad of silica gel. The solvent was then removed, and the residue washed with hexane followed by extraction with diethyl ether. Removal of the ether afforded a purple solid which was recrystallized from a DCM/hexane solvent mixture to give $\left[\mathrm{Co}_{2} \mathrm{Pt}_{2}(\mathrm{IPr})_{2}\left(\mu_{2}-\mathrm{CO}\right)_{4}(\mathrm{CO})_{4}\right](4)$ as purple crystals. (Yield $=27.4 \mathrm{mg}$, 82\%). IR (Et $2 \mathrm{O}): v_{\mathrm{CO}} 2034$ (w), 2018 (s), 2002 (w), 1978 (vs), 1942 (vw), 1837 (m), 1817 (s), $1796(\mathrm{w}) \mathrm{cm}^{-1} .{ }^{1} \mathrm{H}$ NMR (300 MHz, $\mathrm{C}_{6} \mathrm{D}_{6}$ ): $\delta 7.08$ (d, 4H, meta-Ar-H), 6.52 (t, 2H, Imidazole $\left.\mathbf{H}\right)$, 2.97 (sept, 4H, $\left.\mathrm{CH}\left(\mathrm{CH}_{3}\right)_{2}\right), 1.44$ (dd, 12H, $\left.\mathrm{CH}\left(\mathrm{CH}_{3}\right)_{2}\right), 0.92\left(\mathrm{dd}, 12 \mathrm{H}, \mathrm{CH}\left(\mathrm{CH}_{3}\right)_{2}\right)$. ESI-MS ${ }^{+} \mathrm{m} / \mathrm{z}$ :

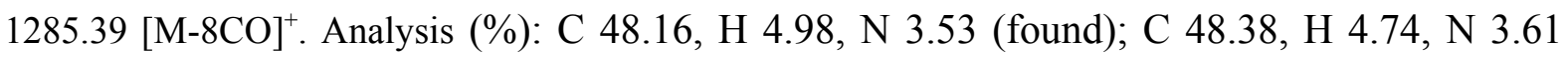
(calcd for $\mathrm{C}_{62} \mathrm{H}_{72} \mathrm{Co}_{2} \mathrm{~N}_{4} \mathrm{O}_{8} \mathrm{Pt}_{2} \cdot 0.5 \mathrm{CH}_{2} \mathrm{Cl}_{2}$ ).

\subsection{Reaction of 2 with [Pt(IPr)]}

A solution of $6(19.5 \mathrm{mg}, 0.0289 \mathrm{mmol})$ and $\mathrm{KO}{ }^{\mathrm{t}} \mathrm{Bu}(3.3 \mathrm{mg}, 0.029 \mathrm{mmol})$ in IPA (10 mL) was heated at $80{ }^{\circ} \mathrm{C}$ for $1 \mathrm{~h}$ to give a yellow solution. The solvent was removed under vacuum to give a yellow oil which was redissolved in DCM $(10 \mathrm{~mL})$ to which $2(6.2 \mathrm{mg}, 0.014 \mathrm{mmol})$ was added. The reaction mixture was stirred at $\mathrm{RT}$ for $15 \mathrm{~h}$ during which the solution turned dark brown. After removal of the solvent, the residue was re-dissolved in a minimum volume of DCM and separated by TLC with hexane:DCM $(5: 2, \mathrm{v} / \mathrm{v})$ as the eluent. Two major bands were isolated and characterized. 
The first major band afforded a green solid which was recrystallized from diethyl ether to afford $\left[\mathrm{Co}_{4} \mathrm{Pt}_{2}\left(\mu_{6}-\mathrm{C}\right)(\mathrm{IPr})_{2}\left(\mu_{2}-\mathrm{CO}\right)_{5}(\mathrm{CO})_{6}\right](5)$ as dark green crystals. (Yield $\left.=5.4 \mathrm{mg}, 29 \%\right)$. IR (DCM): $v_{\mathrm{CO}}$ 2047 (vw), 2010 (vs), 1846 (m), 1819 (m, sh) cm ${ }^{-1} .{ }^{1} \mathrm{H}$ NMR (400 MHz, $\mathrm{CDCl}_{3}$ ): $\delta 7.05$ (d, 4H, metaAr-H), 6.73 (t, 2H, Imidazole H), 2.97 (sept, 4H, $\left.\mathbf{C H}\left(\mathrm{CH}_{3}\right)_{2}\right), 1.43$ (dd, 12H, $\left.\mathrm{CH}\left(\mathrm{CH}_{3}\right)_{2}\right), 0.89$ (dd, 12H, $\left.\mathrm{CH}\left(\mathrm{CH}_{3}\right)_{2}\right) . \mathrm{ESI}_{-\mathrm{MS}}^{+} \mathrm{m} / \mathrm{z}: 1723.25[\mathrm{M}]^{+}, 1695.26[\mathrm{M}-\mathrm{CO}]^{+}, 1639.25[\mathrm{M}-3 \mathrm{CO}]^{+}$.

The second purple-brown band yielded a purple solid which was identified to be cluster 4 by its IR spectrum. (Yield = $3.3 \mathrm{mg}, 20 \%$ ).

\subsection{Reaction of 3 with [Pt(IPr)]}

A sample of 6 (21.1 mg, $0.0329 \mathrm{mmol})$ and $\mathrm{KO}{ }^{\mathrm{t}} \mathrm{Bu}(3.5 \mathrm{mg}, 0.033 \mathrm{~mol})$ were heated to $80{ }^{\circ} \mathrm{C}$ in IPA ( $5 \mathrm{~mL})$ for $1 \mathrm{~h}$. The yellow oil obtained after removal of the solvent was re-dissolved in toluene $(10 \mathrm{~mL})$ to which $3(5.97 \mathrm{mg}, 0.0104 \mathrm{mmol})$ was added. The reaction mixture was left to stir for $15 \mathrm{~h}$ during which it turned to purple-brown. After removal of the solvent, the residue was re-dissolved in a minimum amount of DCM and separated by TLC with hexane:DCM $(1: 1, \mathrm{v} / \mathrm{v})$ as eluent to afford 4 as the major product. (Yield $=17.8 \mathrm{mg}, 56 \%$ ).

\subsection{X-ray crystallographic studies}

The crystals were mounted on quartz fibres. X-ray data were collected at $103 \mathrm{~K}$ on a Bruker Kappa diffractometer equipped with a CCD detector, employing Mo K $\alpha$ radiation $(\lambda=0.71073 \AA)$, with the SMART suite of programs [18]. The data was processed and corrected for Lorentz and polarisation effects with SAINT [19], and for absorption effects with SADABS [20]. Structural solution and refinement were carried out with the SHELXTL suite of programs [21]. The structures were solved by direct or Patterson methods to locate the heavy atoms, followed by successive difference maps for the light, non-hydrogen atoms. All non-hydrogen atoms were refined with anisotropic thermal parameters in the final model.

The crystal of 4 exhibited disorder of the diisopropylphenyl groups as well as the CO ligands and the cobalt atoms. These were modeled with two alternative sites each, with equal occupancies, and 
appropriate restraints were applied. A diethyl ether solvate was found in the asymmetric unit of the crystal of 5. Crystal and refinement data are summarized in Table 1.

\subsection{Computational studies}

Computational studies were carried out with the Gaussian 09W suite of programs, with the M06L density functional, utilizing def2SVP basis set for Pt atoms, while the 6-31G* basis set is used for the remaining atoms [22]. Natural Bond Orbital (NBO) analysis was carried out with the NBO 3.1 program implemented within Gaussian 09W [23].

\section{Acknowledgements}

This work was supported by Nanyang Technological University and the Ministry of Education (Research Grant No. M4011158). BYC thanks the Agency for Science, Technology and Research (A*STAR, Singapore) for a Graduate Scholarship.

Supplementary material: Crystallographic data (excluding structure factors) for the structures in this paper have been deposited with the Cambridge Crystallographic Data Centre as supplementary publication numbers CCDC 1532322 and 1532323 for $\mathbf{4}$ and 5, respectively. Copies of the data can be obtained, free of charge, on application to CCDC, 12 Union Road, Cambridge CB2 1EZ, UK, (fax: +44 1223336033 or e-mail: deposit@ccdc.cam.ac.uk). 
Table S1. Crystal and structure refinement data for complexes $\mathbf{4}$ and $\mathbf{5 .}$

\begin{tabular}{|c|c|c|}
\hline Complex & 4 & 5 \\
\hline Empirical formula & $\mathrm{C}_{62} \mathrm{H}_{72} \mathrm{Co}_{2} \mathrm{~N}_{4} \mathrm{O}_{8} \mathrm{P}_{\mathrm{t} 2}$ & $\mathrm{C}_{66} \mathrm{H}_{72} \mathrm{Co}_{4} \mathrm{~N}_{4} \mathrm{O}_{12} \mathrm{Pt}_{2} . \mathrm{Et}_{2} \mathrm{O}$ \\
\hline Formula weight & 1509.28 & 1797.29 \\
\hline Crystal system & Monoclinic & Monoclinic \\
\hline Space group & $\mathrm{P} 2{ }_{1} / \mathrm{n}$ & $\mathrm{P} 2{ }_{1} / \mathrm{n}$ \\
\hline $\mathrm{a}, \AA$ & $13.048(2)$ & $12.5072(15)$ \\
\hline $\mathrm{b}, \AA$ & $14.253(2)$ & $31.460(4)$ \\
\hline $\mathrm{c}, \AA$ & $16.460(3)$ & $18.748(3)$ \\
\hline$\beta, \operatorname{deg}$ & $98.476(12)$ & $102.637(5)$ \\
\hline Volume, $\AA^{3}$ & $3027.8(8)$ & $7198.3(15)$ \\
\hline $\mathrm{Z}$ & 2 & 4 \\
\hline Density (calculated), $\mathrm{Mg} / \mathrm{m}^{3}$ & 1.655 & 1.658 \\
\hline Absorption coefficient, $\mathrm{mm}^{-1}$ & 5.200 & 4.832 \\
\hline $\mathrm{F}(000)$ & 1492 & 3560 \\
\hline Crystal size, $\mathrm{mm}^{3}$ & $0.22 \times 0.12 \times .0 .10$ & $0.34 \times 0.14 \times 0.06$ \\
\hline Reflections collected & 47666 & 119217 \\
\hline Independent reflections & $6186[\mathrm{R}(\mathrm{int})=0.1315]$ & $14704[\mathrm{R}(\mathrm{int})=0.1698]$ \\
\hline Max. and min. transmission & 0.6244 and 0.3942 & 0.76 and 0.29 \\
\hline Data / restraints / parameters & $6186 / 566 / 473$ & 14704 / 516 / 847 \\
\hline Goodness-of-fit on $\mathrm{F}^{2}$ & 1.094 & 1.197 \\
\hline Final $R$ indices $[\mathrm{I}>2 \mathrm{~s}(\mathrm{I})]$ & $\begin{array}{l}\mathrm{R} 1=00417 \\
\mathrm{wR} 2=0.0 .0986\end{array}$ & $\begin{array}{l}\mathrm{R} 1=0.0792 \\
\mathrm{wR} 2=0.1679\end{array}$ \\
\hline $\mathrm{R}$ indices (all data) & $\begin{array}{l}\mathrm{R} 1=0.0676 \\
\mathrm{wR} 2=0.1257\end{array}$ & $\begin{array}{l}\mathrm{R} 1=0.1264 \\
\mathrm{wR} 2=0.1893\end{array}$ \\
\hline Largest diff. peak and hole, e. $\AA^{-3}$ & 1.362 and -1.534 & 2.772 and -3.165 \\
\hline
\end{tabular}




\section{Reference}

1 (a) J.H. den Otter, H. Yoshida, C. Ledesma, D. Chen, K.P. de Jong, J. Catal. 340 (2016) 270-275. (b) J.H. den Otter, S.R. Nijveld, K.P. de Jong, ACS Catalysis 6 (2016) 1616-1623. (c) V. Montes, M. Boutonnet, S. Järås, M. Lualdi, A. Marinas, J.M. Marinas, F.J. Urbano, M. Mora, Catal. Today 223 (2014) 66-75.

2 (a) A. Nouralishahi, A.M. Rashidi, Y. Mortazavi, A.A. Khodadadi, M. Choolaei, Appl. Surf. Sci. 335 (2015) 55-64. (b) V. Kepenienè, L. Tamašauskaitè-Tamašiūnaitė, J. Jablonskienè, M. Semaško, J. Vaičiūnienė, R. Vaitkus, E. Norkus, Mater. Chem. Phys. 171 (2016) 145-152. (c) H. Yang, J. Deng, Y. Liu, S. Xie, P. Xu, H. Dai, Chinese Journal of Catalysis 37 (2016) 934-946. (d) X. Yu, H. Li, S.-T. Tu, J. Yan, Z. Wang, Int. J. Hydrogen Energy 36 (2011) 3778-3788. (e) A. López, N. Navascues, R. Mallada, S. Irusta, Appl. Catal., A 528 (2016) 86-92.

3 See, for example: (a) B. F. G. Johnson, Coord. Chem. Rev. 190-192 (1999) 1269. (b) B.F.G. Johnson, Top. Catal. 24 (2003) 147. (c) J. M. Thomas, B.F.G. Johnson, R. Raja, G. Sankar, P.A. Midgley, Acc. Chem. Res. 36 (2003) 20. (d) A. C. W. Koh, W.K. Leong, L. Chen, T.P. Ang, J. Lin, B.F.G. Johnson, T. Khimyak, Catal. Commun. 9 (2008) 170. (e) S. Zacchini, Eur. J. Inorg. Chem. (2011) 4125. (f) P. Buchwalter, J. Rosé, P. Braunstein, Chem. Rev. 115 (2015) 28.

4 P. Buchwalter, J. Rosé, P. Braunstein, Chem. Rev. 115 (2015) 28-126.

5 J.C. Jeffery, M.J. Parrott, F.G.A. Stone, J. Organomet. Chem. 382 (1990) 225-235.

6 (a) Y. Liu, R. Ganguly, H.V. Huynh, W.K. Leong, Organometallics 32 (2013) 7559-7563. (b) Y. Liu, $\mathrm{PhD}$ thesis, Nanyang Technological University, (2014).

7 J. Fischer, A. Mitschler, R. Weiss, J. Dehand, J.F. Nennig, J. Organomet. Chem. 91 (1975) C37-C38. 8 (a) R. Bender, P. Braunstein, Y. Dusausoy, J. Protas, J. Organomet. Chem. 172 (1979) C51-C54. (b) F.G.A. Stone, Inorg. Chim. Acta 50 (1981) 33-42.

9 P. Braunstein, C. De Meric de Bellefon, S.E. Bouaoud, D. Grandjean, J.F. Halet, J.Y. Saillard, J. Am. Chem. Soc. 113 (1991) 5282-5292.

10 I. Ciabatti, F. Fabrizi de Biani, C. Femoni, M.C. Iapalucci, G. Longoni, S. Zacchini, ChemPlusChem 78 (2013) 1456-1465.

11 V.G. Albano, D. Braga, S. Martinengo, J. Chem. Soc., Dalton Trans. (1986) 981-984.

12 V. Singh, M. Dixit, M. Kosa, D.T. Major, E. Levi, D. Aurbach, Chem. Eur. J. 22 (2016) 52695276.

13 (a) E.P. Fowe, B. Therrien, G. Süss-Fink, C. Daul, Inorg. Chem. 47 (2008) 42-48. (b) S.P. Oh, B.Y. Chor, W.Y. Fan, Y. Li, W.K. Leong, Organometallics 30 (2011) 6774-6777.

14 H. Wang, Y. Xie, R.B. King, H.F. Schaefer, J. Am. Chem. Soc. 128 (2006) 11376-11384.

15 I. Ciabatti, C. Femoni, M. Hayatifar, M.C. Iapalucci, S. Zacchini, Inorg. Chim. Acta 428 (2015) 203-211. 
16 (a) T. Sugihara, A. Wakabayashi, Y. Nagai, H. Takao, H. Imagawa, M. Nishizawa, Chem. Commun. (2002) 576-577. (b) M.O. Nestle, J.E. Hallgren, D. Seyferth, P. Dawson, B.H. Robinson, Inorg. Synth. 20 (1980) 226-229.

17 S. Fantasia, S.P. Nolan, Chem. Eur. J. 14 (2008) 6987-6993.

18 SMART Version 5.628, Bruker AXS Inc., Madison, Wisconsin, USA, 2001.

19 SAINT+ Version 6.22a, Bruker AXS Inc, Madison, Wisconsin, USA, 2001.

20 Sheldrick, G.M. SADABS; University of Göttingen, Göttingen, Germany, 1996.

21 SHELXTL Version 5.1, Bruker AXS Inc, Madison, Wisconsin, USA, 1997.

22 M.J. Frisch, G.W. Trucks, H.B. Schlegel, G.E. Scuseria, M.A. Robb, J.R. Cheeseman, G. Scalmani, V. Barone, B. Mennucci, G.A. Petersson, H. Nakatsuji, M. Caricato, X. Li, H.P. Hratchian, A.F. Izmaylov, J. Bloino, G. Zheng, J.L. Sonnenberg, M. Hada, M. Ehara, K. Toyota, R. Fukuda, J. Hasegawa, M. Ishida, T. Nakajima, Y. Honda, O. Kitao, H. Nakai, T. Vreven, J.A. Montgomery, P.J.J. E., F. Ogliaro, M. Bearpark, J.J. Heyd, E. Brothers, K.N. Kudin, V.N. Staroverov, R. Kobayashi, J. Normand, K. Raghavachari, A. Rendell, J.C. Burant, S.S. Iyengar, J. Tomasi, M. Cossi, N. Rega, J.M. Millam, M. Klene, J.E. Knox, J.B. Cross, V. Bakken, C. Adamo, J. Jaramillo, R. Gomperts, R.E. Stratmann, O. Yazyev, A.J. Austin, R. Cammi, C. Pomelli, J.W. Ochterski, R.L. Martin, K. Morokuma, V.G. Zakrzewski, G.A. Voth, P. Salvador, J.J. Dannenberg, S. Dapprich, A.D. Daniels, Ö. Farkas, J.B. Foresman, J.V. Ortiz, J. Cioslowski, D.J. Fox, Gaussian 09, revision D.01, Gaussian, Inc., Wallingford CT (2009).

23 E.D. Glendening, A.E. Reed, J.E. Carpenter, F. Weinhold, The NBO 3.1 program. 